\title{
An Analysis of Pure-Revenue Technology Licensing*
}

\author{
Neus Palomeras \\ Department of Business Economics \\ Universidad Carlos III de Madrid \\ C/ Madrid, 126, Getafe \\ 28903 Madrid, Spain \\ neus.palomeras@uc3m.es
}

* I thank Bruno Cassiman, Andrea Fosfuri, Eduardo Melero and two anonymous referees for their helpful suggestions. All remaining errors are my own. 


\begin{abstract}
This paper analyzes the incentives of patentholders to license their technologies for pure-revenue reasons. We hypothesize that this decision is mainly driven by characteristics of the innovation, which determine its technological attractiveness, the relevance of transaction costs in its transfer and the importance of the competition effect. By using the NBER Patent Citations Database and an original dataset of patented technologies devoted to license in an Internet marketplace, we find that importance, innovativeness, fit into the firm's core and scope of the innovation affect the patentholder's willingness to license it. Results increase our awareness on the drivers of technology licensing decisions.
\end{abstract}




\section{INTRODUCTION}

Licensing technologies is not a new phenomenon. However, in the last years it has increased considerably (Arora \& Fosfuri, 2003). Practices such as to mine patent portfolios for royalties arose in the late-1980s or early-1990s, when important patentholders such as IBM or Texas Instruments resorted to it to face financial pressures -nowadays, royalties represent for these firms around \$1billion a year- (Rivette \& Kline, 2000). Indeed, these authors present licensing as an option to generate revenues from unexploited technologies, for which the firm had not identified any use in products.

Different estimates suggest that the amount of unused technologies is far from irrelevant. According to a 1998 survey by BTG, 67\% of US firms own unexploited technology assets that amount on average more than one third of their patent portfolio. A survey to European inventors (Giuri et al., 2005) reports a lower bound of $36 \%$ of unexploited patents. This percentage reaches a $50 \%$ in the chemicals and pharmaceutical sector, even though only a $22 \%$ of them are actually unused -the rest are not applied in products but used for strategic purposes such as blocking competitors-. Not only there are unused technologies in firms' portfolios but also underused technologies. Elton et al. (2002) estimate that $10 \%$ of the patent portfolio of a researchintensive company is underexploited and it could generate at least a $5 \%$ of her operating income if licensed. They suggest outside industries as particularly attractive in order to find new uses for unexploited technologies or alternative uses for already exploited technologies ${ }^{1}$. However, this is not a trivial task. A first problem lies on being able to identify worthy applications in unknown sectors. Another limitation is the cost of searching for partners in distant technological and geographical settings due to the 
fragmentation of the market for technology (Arora et al, 2001). Some pioneer firms try to overcome these obstacles by hiring away scientists who conduct basic interdisciplinary research and are able to identify a variety of applications of a technology (Elton et al., 2002) or by listing their technological assets in a public shelve where firms from different industries may have easy access to such as the Internet ${ }^{2}$.

In this paper, we will consider licensing under this view. Our aim is to analyse the use of licensing as a source to obtain revenues from unused or underused technologies by firms with research and development capabilities. We will refer to this type of licensing as pure revenue licensing, in order to distinguish it from licensing practices motivated by other reasons -strategic or related to efficiency-. In particular, we seek to characterize the type of technologies that the mentioned firms are willing to devote to this type of licensing. In order to identify them, we rely on a selection of firms that decide to offer some of their innovations for license in a technology marketplace that, given its characteristics, is assumed to capture only pure revenue licensing.

Licensing out is an alternative to in-house development or, in firms with research and development capabilities, a by-product of it. Licensing allows obtaining revenues but it introduces competition and erodes monopoly profits. The economics literature has suggested different strategic motivations that can lead to the use of licensing by a technology holder that exploits the technology by herself, such as the selection of competitors (Rockett, 1990), the desire to establish a standard or to deter entry (Gallini, 1984). Arora and Fosfuri (2003), however, suggest that when there are technology holders that compete in the product market with substitute technologies, strategic and revenue motivations actually mix up. In this case, licensing limits the negative impact of competitors' licenses and at the same time, it increases total revenues by the firm. The 
management literature (Teece, 1988) has pointed out the use of licensing as a substitute to own development, when the innovator firm is less efficient to exploit a technology than a potential licensee. This view implicitly assumes that the innovator firm evaluates these alternatives having in mind an application for the technology.

Empirical studies on the licensing literature are scarce. Anand and Khanna (2000), in a cross-industry study on licensing contracts, shed light on the relevance of practices such as exclusive contracts, cross-licensing or previous relationships between the parties. Sine et al. (2003) and Fosfuri (2004) examine the determinants of the rate of licensing, in a university setting and in the chemical industry, respectively. The latter analyses it as a function of the market characteristics that shape the balance between royalty revenues and increased competition. Shane (2001), following the entrepreneurship literature, examines the effect of technological opportunity on the decision to create a new firm based on a license from a university patented innovation. Therefore, he analyzes licensing from the perspective of the incentives by the licensees -and a particular group of them, startups-.

This paper aims to contribute to the stream of empirical literature on licensing by understanding, at the innovation level, the technological determinants of firm licensing. We analyze the incentives that a firm with development capabilities has in order to license her innovations as a function of their technological characteristics. We consider that such characteristics affect technological opportunity, costs of transfer and the creation of own competition. We use all these elements to examine the licensing decision in the competition vs. revenue effect framework developed by Arora and Fosfuri (2003). Our focus on the nature of the technology excludes from the analysis 
any strategic reason involved in licensing decisions; therefore, our research is constrained to licensing decisions motivated by revenue earning.

The paper is organized as follows. Next section develops the theoretical background. In the third section, we explain the empirical methodology used. The fourth describes the data and variables. The fifth section presents the empirical results and the sixth concludes.

\section{THEORETICAL BACKGROUND}

A license on a patent protected technology consists of a contract for which its legal holder gives the right to exploit the technology to a third party in exchange for some upfront fee or/and royalties. Independently of the motivation that leads to licensing, the underlying constant is the development of the innovation. Therefore, the nature of the technology is likely to affect, in a higher or lower degree, its attractiveness for being licensed. Nevertheless, this aspect has been clearly underestimated by the licensing literature, with exceptions such as Teece (1986) and Winter (1987). We will analyze the licensing decision under this prysma in the framework of the revenue vs. competition effect theory (Arora and Fosfuri, 2003).

In pure-revenue licensing, where the only aim of the patent holder is to attract a third party who exploits her innovation, technological opportunity is a key driver. Shane (2001) gathers some dimensions of it -importance, innovativeness and patent scope- in order to analyze the likelihood to create a firm from a university patented technology. The nature of the technology, thus, drives the willingness to license by the patent 
holder, who anticipates the interest of potential licensees and, thus, the magnitude of the revenue effect. However, technological opportunity is also a driver in the decision to exploit a technology by the patentholder. This implies that it will affect her willingness to license, since licensing represents extra competition for the patentholder if she is present in the product market. The intensity of this negative effect will depend on the nature of competition of the market. Therefore, the most likely candidates to be devoted to pure-revenue licensing are unexploited technologies, which do not introduce competition at all. This is also the case of technologies with multiple applications, some of which remain non-developed by the patentholder. This potential to be used in multiple domains is as well determined by the nature of the technology.

The characteristics of the innovation also affect the transaction costs that the transfer of technology involves, diminishing the expected revenue effect from licensing. Any contract entails transaction costs (Williamson, 1991) but in the case of technology transfer, these are especially stringent. As Arora et al. (2001) point out, the fragmentation of the market for technology across sectors and geographical regions causes important coordination costs, mainly search costs. Thus, the technological dimensions, by turning the innovation particularly attractive for a certain type of licensees, will influence how costly will be to reach them. Motivation costs are originated by the partners' potential opportunistic behavior, fuelled by the information asymmetries and uncertainty usually present in knowledge transactions. Characteristics of the knowledge asset transacted such as its tacitness, complexity or independence (Winter, 1987) influence the presence of these problems and, thus, the easiness of transfer. The technological distance between the domains of licensor and licensee 
affects as well the relevance of motivation costs, given the highly context dependence of knowledge (Arora et al, 2001).

Motivation costs may be mitigated in settings where repeated or long-term interactions allow firms to build up reputation or to threaten potential opportunism credibly (Arora et al, 2001). These contractual mechanisms typically arise in networks of firms from the same sector and region, with which coordination costs are also minimal. Therefore, in pure revenue licensing, the likely licensee targets does not usually belong to the patentholder's networks. This means that this type of licensing is left to the spot market, where transaction costs may thwart deals. Coordination costs to find a potential licensee from a different sector or region constitute a huge barrier. The lack of mechanisms to soften motivation costs may also deter potential deals, even if we expect them to be less relevant than when licensing involves strategic issues. In this scenario, the Internet offers the possibility to create a marketplace that overcomes transaction costs without introducing the rigidities of traditional technology markets, as it has been the case in many business-to-business markets (Garicano and Kaplan, 2001). Different Internetbased firms were created with the aim to broaden the market for technology. They claimed to offer platforms that allowed, first, to get access to a geographically and sectorially broad market of licensees with basically absent coordination costs and second, to put in place non-restrictive mechanisms to cope to a certain extent with motivation costs. This setting is, thus, especially attractive for pure-revenue licensing.

In such a scenery, we will examine which technological dimensions of an innovation turn patentholders more willing to license it for pure-revenue reasons. We will consider four ${ }^{3}$ : importance, scope, innovativeness and fit. Importance anticipates valuable 
technological opportunities and, consequently, a high revenue effect. Scope, a broad range of would-be applications across the technological space and a strong legal protection. Innovativeness translates into non-developed opportunities by incumbents. Fit into the firm strategy favors own development over licensing, which anticipates high motivation costs. We develop next how these dimensions affect the willingness to license -in order to obtain revenues- by an established firm with research and commercialization capabilities in a sector with an active market for technology $y^{4}$.

\subsection{Hypotheses}

One of the most significant dimensions of an innovation is its technological relevance or importance. Technological value has been found positively correlated with the economic value of innovations ${ }^{5}$ (Harhoff et al., 1999; Hall et al. 2005). Therefore, an important innovation raises interests to be commercially exploited. This means that it is especially attractive for potential licensees, who will be willing to pay for the license, as well as for the patentholder, who will be willing to exploit it in the first place. Therefore, importance suggests both a revenue and a competition effect. We should as well take into account that licensing an important innovation may anticipate high motivation costs, fact that decreases the prospects for revenues. Nevertheless, in industries proactive in licensing, the concerns on motivation costs become less relevant with the perspective of obtaining revenues, as Arora et al. (2001) report for the chemical sector. The question, therefore, is whether the prospects for licensing revenues can compensate the fall in profits due to an increasing competition in the product market. Hence, the effect of importance on the licensing likelihood is ambiguous. 
Innovative technologies, as their name suggest, represent a breakthrough with respect to previous technologies. Arrow (1962) defines an innovation as drastic if it turns the old technology obsolete. For an incumbent, it means that the new technology will cannibalize the rents she obtains from the existing product or process. Therefore, her incentive is to not develop the innovation. On the contrary, entrants, with no rents to be cannibalized, are more willing to (Arrow, 1962; Reinganum, 1983). Shane (2001) finds that entrepreneurs are more likely to pick up more innovative patents in order to set up a new firm. However, when the incumbent who generated such innovation has to negotiate its commercialization with a start-up, the result is either internal development or shelving, depending on whether she may soften cannibalization through in-house mechanisms or not (Cassiman and Ueda, 2006). As well, the adoption of technologically novel innovations usually requires radical organizational changes, since it requires new competences that render existing procedures obsolete (Tushman and Anderson, 1986). Since organizational change is difficult and risky, incumbents remain less productive to exploit such innovations (Henderson, 1993). Innovativeness, therefore, is a dimension that anticipates interest by start-up licensees, both from a technological and an organizational point of view. However, the incumbent will only make the technology available for license in sectors or market niches that do not present risk of cannibalization, i.e. the ones where she is not active. Traditional licensing markets anticipate huge coordination costs in order to get access to potential start-up licensees in these typically distant markets. Therefore, the existence of a market that alleviates such costs gives incentives to the incumbent to license such innovations. Thus, the effect of innovativeness on the incentives for pure-revenue licensing is expected to be positive. 
The fit of an innovation is the degree to which it falls within the core activity of the firm. Cassiman and Ueda (2006) define it as the cost saving from internal development with respect to external; consequently, innovations with a high fit are internally exploited. The source of this cost advantage lies on the organizational and technical capabilities that established firms develop associated with their core activities in order to appropriate value (Teece, 1986). Therefore, it follows from the same concept of fit that there is a disparity between the value that a core technology represents for the patentholder and for potential licensees. Obviously, this gap will disappear to the extent that the firm's core capabilities were transferred to the latter. The patentholder's incentives to do so depend on two opposite forces. On the one hand, an innovation from the core results attractive for a potential licensee as it reduces the information asymmetries present in knowledge transactions. That is, it signals that there is a reliable know-how behind the innovation, which turns the innovation more valuable to potential licensees. This point should be especially important to reach licensees out of the firm markets, where the competition effect is null and information asymmetries are large. On the other hand, the transfer of core knowledge implies the disclosure of the patentholder' sources of competitive advantage, entailing high motivation costs. In general, this effect is likely to prevail over the former, since its negative consequences are not exclusively linked to the particular innovation but they stretch out to other core related technologies. Thus, the effect of fit on the incentives for pure-revenue licensing is expected to be negative.

There is one particular case, though, in which the reduction of information asymmetries associated with the patentholder's reputation in her core activities can offset the negative effects of licensing a core innovation. This is when the innovation happens to 
be technologically relevant. Indeed, there is a potential complementarity between fit and importance. The reduction in information asymmetries with respect to the quality of the innovation is likely to become more valuable as the relevance of the technology increases. The reason lies on the fact that a signal that reduces uncertainty is worthier when there is more value at stake. Hence, the effect of important patents in the firm's core on the likelihood of pure-revenue licensing is expected to be positive.

Scope, or broadness, is a dimension that refers to the technological space the innovation covers. A broad innovation is a generic or basic technology from which a lot of applications can be derived ${ }^{6}$. In patent protected technologies, the larger the scope, the larger the number of potential products that will infringe the patent (Merges and Nelson, 1990). Scope, therefore, offers a broad range of technological opportunities unlikely to be drained off by the technology holder through own development or traditional licensing. The reason lies on the fact that both alternatives are usually restricted to exploit applications around the usual technological space of the firm. A setting of low coordination costs that facilitates transactions with potential licensees across the technological space would favor the exploitation of the distant applications. In patent protected technologies, scope is also shaped by how inventors -or their lawyers- "design" the patent, i.e. by the legal description of the innovation. Firms have incentives to widen the legal scope because it strengthens the protection of the innovation $^{7}$. Shane (2001) finds that broadness confers an extra protection that is especially valuable to entrepreneurs meanwhile they acquire the assets needed to develop the technology. Lerner (1994) finds that broader biotech patents protect more important inventions and firms holding them receive larger valuations in the venture capital investment process. Independently of the direction of the causality between 
broadness and protection, the key is that the stronger legal protection associated with broad innovations is worthwhile in licensing transactions (Arora and Gambardella, 1994; Anand and Khanna, 2000), especially when the risks involved increase. Therefore, we expect that broadness has a positive effect on the incentives for purerevenue licensing, due to the interdisciplinarity and extra protection it anticipates.

\section{EMPIRICAL MODEL}

We would like to estimate the probability that a patent holder is willing to license a given patented innovation for pure-revenue purposes. The outcome variable is a binary dependent variable that captures the decision by the firm whether or not to offer each patent for pure revenue licensing ${ }^{8}$. We should therefore use a discrete choice model with the following specification for patent $j$ in firm $i$ :

$Y^{*}{ }_{i j}=\beta^{\prime} X_{i j}+\varepsilon_{i j}+\alpha_{i} \quad$ where $\left\{\begin{array}{l}Y_{i j}=1 \\ Y_{i j}=0\end{array} \quad\right.$ if $\quad \begin{array}{r}Y^{*}{ }_{i j}>0 \\ Y^{*}{ }_{i j} \leq 0\end{array} \quad j=1,2, \ldots \mathrm{N}_{i} ; \quad i=1,2, \ldots \mathrm{I}$

where $\mathrm{Y}^{*}{ }_{i j}$ denotes the unobservable propensity of $i$ 's willingness to license $j$ for revenue purposes, $X_{i j}$ is a vector of patent-varying exogenous variables, $\varepsilon_{i j}$ is the unobservable error term and $\alpha_{i}$ is a variable that captures the firm specific unobserved effects. The $\alpha_{i}$ variable should be introduced to the model given that we can not assume independence on the error terms. Since there are many patents in the sample owned by a given firm $i$, each firm represents a cluster of correlated observations. The dilemma is whether $\alpha_{i}$ should be treated just as a constant term over firms (fixed effects model) or as a random variable like the error term (random effects model). The latter approach obtains more efficient estimates but it requires the assumption that the $\alpha_{i}$ 's are 
independent of the $\mathrm{X}_{\mathrm{ij}}$ 's if our estimates are to be consistent. The Hausman test allows testing this assumption (Maddala, 1993). We do not find conclusive evidence for the rejection of the null hypothesis of consistency of the random effects model. Moreover, we are interested in including some firm-invariant variables $\left(\mathrm{z}_{\mathrm{i}}\right)$ such as the size of the firms' patent portfolio. In this case, if we used the fixed effects model we could not estimate their parameters $(\gamma)$, because $\alpha_{i}$ captures the effect of all firm-invariant variables. Therefore, we treat $\alpha_{i}$ as random. The specification is as follows:

$$
Y_{i j}^{*}=\alpha_{i}+\beta^{\prime} X_{i j}+\gamma^{\prime} z_{i}+\varepsilon_{i j}
$$

The probit model is the most appropriate discrete choice technique to estimate it. The multivariate normal distribution in which it is based upon is more flexible than the multivariate logistic distribution (Maddala, 1993). Therefore, we use a probit random effects model.

\section{DATA AND VARIABLES}

\subsection{Data}

We rely on data on patent protected innovations. The first reason is that intellectual property protection increases the likelihood of transacting with the protected knowledge (Arora et al., 2001). The second is data availability. We use the NBER Patent Citations Data File (Hall, Jaffe \& Trajtenberg, 2001) that contains the population of patents granted by the USPTO from 1963 to 1999 . This database includes codified information at the patent level on many variables that characterize them and that we will use as proxies for innovation dimensions. Nevertheless, there is no information on the use of 
the patent by its assignee. How then to identify the innovations that are intended for pure-revenue licensing?

Since, as previously mentioned, pure-revenue licensing is likely to be captured in a setting like the Internet, we turn to it in order to identify a marketplace devoted to this type of licensing. We focus on yet2.com, the main firm created with this aim on the Internet at the time of data collection (first half of 2002) and one of the few that has survived $^{9}$. yet2.com attracted well known research intensive corporations as suppliers of licensable patent protected technologies, that were listed for a fee in the yet2.com site, classified by technological category and with a brief technological description, accessible to anyone. Owners, in order to get their innovations listed, and seekers, in order to get in contact with the owner, must pay a fee ${ }^{10}$. These fees are thought to alleviate to a minimum extent disclosure concerns and adverse selection problems in the supply of technologies. The only mechanism at work to reduce the uncertainties around licensors' moral hazard is reputation in the general market -this is the reason why mainly well known firms are attracted as suppliers-. To sum up, yet2.com offers to technology holders the opportunity to reach a broad market, in geographical and sectorial terms, incurring in negligible search costs but substantial motivation costs. Therefore, we assume that all the patents present in this marketplace are posted for pure-revenue licensing.

Therefore, we identify the patent protected innovations for license at yet2.com and the firms that offer them ${ }^{11}$. We restrict our attention to firms ${ }^{12}$ that offer innovations related with the Chemicals and Biotechnology, two sectors with an active market for technology, where firms are used to profiting from in-house $R \& D$ through licenses as 
well as to using externally developed technology (Arora et al., 2001). We select them if they fall under these categories according to the yet2.com and the USPTO classification $^{13}$. We end up with 904 patents granted to 87 different firms. Then, thanks to the NBER Patent Citations Data File, we identify the population of chemical and biotechnology patents applied by this set of firms from 1982 to 1999. Once subtracted from this population the patents not present in the Internet licensing marketplace ${ }^{14}$, we draw a $10 \%$ random sample (8337 observations) that forms the control group ${ }^{15}$.

\subsection{Variables}

The dependent variable captures whether the patent holder is willing to license for purerevenue reasons each patent. As argued above, we assume that this willingness is reflected by posting the patent in the yet2.com marketplace. We assume that each patent identified there proxies for an innovation ${ }^{16}$. Relevant explanatory variables are described next.

Recent literature has suggested as proxy for importance the number of citations a patent receives from subsequent patents. When an inventor patents an innovation, he must cite the scientific prior art (previous papers and patents) he has built upon. Therefore, the citations received by a given patent can be interpreted as its contribution to science (Jaffe et. al 2000). Different authors have tested the positive correlation between this measure and different aspects of value such as social value (Trajtenberg, 1990), stockmarket value (Hall et al., 2005) or commercial value of the innovation (Harhoff et al., 1999). However, citations present a practical problem: since data is truncated at a certain point in time, patents granted closer to it have a shorter time span to receive 
citations. In order to remove variance due to truncation, we standardize the data by year and sector following Hall et al. (2001). Alternatively, we simply introduce year dummies (Shane, 2001).

The degree of innovativeness is measured by the citations made to previous patents, which represent the knowledge that helps to shape the innovation. Therefore, the pattern of citations made tells us to what extent the innovation represents a break with the previous state of the art or a smooth continuity. An entire original creation is considered innovative but it is also the combination of existing knowledge from different disciplines. The first view is captured by Lanjouw \& Schankerman (1999), who consider that a low number of citations made reflect an innovation less derivative and more genuine in nature. The second idea is seized by looking at the dispersion across patent classes of the cited patents. Hall et al (2001) capture it through originality, a Herfindhal-like index that measures the concentration of citations across patent classes ${ }^{17}$ -a higher spread of citations made across classes suggests that the invention is not sequential but that it "breaks molds"-.

We measure the strategic fit of an innovation in the firm strategy by the weight that represents its patent class in the firms' patent portfolio. Following Song et al (2003), we construct a dummy variable, core, which captures whether a patent class of a given innovation coincides with the highest frequent classes in the firm's portfolio ${ }^{18}$.

In order to measure scope, we follow Trajtenberg et al (1992), who suggest that the spread of citations received across patent classes proxies for the technological space the patent covers, since they indicate the sectors of activity in which the innovation is 
applied to. They measure this spread by a Herfindhal-type concentration index of citations received, generality ${ }^{19}$. Lanjouw \& Schankerman (1999) propose a measure that takes into account the directly protected space: the number of claims, the sentences that describe an invention and that are interpreted as "units of invention" (Jaffe, Hall \& Trajtenberg, 1999) ${ }^{20}$

We introduce two different sets of control variables. The first is related with different patent characteristics: number of inventors responsible for the innovation, percentage of self-citations (both made and received), time and technological category. The number of inventors points out to the amount and diversity of knowledge sources that lead to the innovation, that may influence its characteristics -such as importance, interdisciplinarity or complexity- as well as its transfer -more difficult if the know-how associated to the blueprint is dispersed. Self-citations refer to citations a patent makes to or receives from patents owned by the same firm and reflect internal flows of knowledge (Hall et al, 2001). Therefore, it is important to control for them in order to capture the true meaning of external citations. Citing the firm's own patents is a signal of persistence of an existing internal research line. Self-citations received reflect the relevance of the innovation within the firm as subsequent research builds upon it. The time control introduced via the application year of the patent- is required because citation-related variables are time-dependent. Finally, since the majority of the independent variables vary with technological field, we control for technological category -built upon patent classes (Hall et al., 2001)-. The second set of control variables is related with two firm characteristics: size and diversification, which may affect the firm's willingness to license as well as the characteristics of her patents and innovations ${ }^{21}$. Size is meant to control for experience in managing intellectual property and access to traditional 
licensing networks. The most appropriate measure in this setting is patent portfolio, the number of USPTO patents granted to the firm in the years previous to the licensing decision. Diversification may result in more interdisciplinary innovations, more opportunities to exploit them and more accessible licensing networks. We compute a diversification measure following Davis et al. (1994) ${ }^{22}$.

Table 1 presents a summary of variables and Table 2, their descriptive statistics, including a t-test for differences of means between the patents devoted to license and the rest. The two groups of innovations differ significantly across the majority of dimensions -except for citations received and generality-. In Table 3, we present the correlation between the variables, significant at the one percent level for the majority of them. However, the highest correlation coefficients do not suggest the presence of multicollinearity problems, as it is confirmed by high tolerance levels.

\section{EMPIRICAL RESULTS}

In this section, we present the results of the estimation of a probit random effects model. Independent variables have been log transformed in order to reduce their skewness ${ }^{23}$. Table 4 presents the marginal effects ${ }^{24}$ of the different variables on the probability that the patent is offered by pure-revenue licensing. We test four different Specifications.

Specification 1 includes only the proxies that represent raw information coming from the patent document: number of claims describing the invention, number of citations received (creceived) and number of citations made (cmade). The magnitude of the effect 
of each variable is reflected by the percentual increase in the likelihood (indicated by the marginal effect) when its value increases a $1 \%$ from its median, with the rest of variables kept constant at their median. Creceived displays a non-significant positive coefficient. The coefficient on cmade displays an as predicted negative and significant sign. Claims displays a significant positive coefficient, which supports the hypothesis that broader patents are more likely to be the object of pure revenue licensing. We also include a dummy, core, which captures a significant negative effect of the fit of the innovation in the firm's core over the likelihood. We control for portfolio, technological category and application year and we obtain that patents by larger firms, patents applied earlier in time and patents in the drugs and medical category (opposed to patents in the chemicals) are less likely to be licensed for pure-revenue reasons.

In Specification 2, we incorporate two variables built up from the citations: originality and generality. The coefficient of the former, even not significant, reinforces the positive impact of innovativeness. Generality enters positive and significant, supporting the idea that broader patents show up more likely on pure-revenue licensing markets. Creceived, the proxy for importance, turns to negative, even though it remains nonsignificant.

Specification 3 includes the technological controls: inventors and selfcitations. Results remain robust to their introduction, except for core, that loses its significance. The proportion of the total error variance accounted for by the random effect is significant $($ rho=.306). The inventors variable itself presents a highly significant positive coefficient that deserves attention: the higher the number of inventors who worked behind a patent, the higher the likelihood that the patent holder devotes it to pure- 
revenue licensing. This fact may suggest that the resulting innovations are simply more interdisciplinary or that they enjoy a bigger protection at the time of transfer ${ }^{25}$. Selfcitations enter with negative coefficients, significant in the case of self-citations made, which suggests that the more a patent sticks to the research line of the firm, the less likely it is to be licensed.

Specification 4 gathers the effect of the interesting interaction between fit (core) and importance (creceived), which displays an expected significant positive coefficient. The introduction of this interaction turns to significant the negative coefficients on importance and fit. That is, highly valued patents falling in the core are more likely to be licensed than their counterparts that fall out of it, whereas the reverse holds the less important they are. Actually, the overall effect of citations turns to positive for patents in the core with more than two citations received, i.e. moderately important ${ }^{26}$. This result supports the hypothesis that important innovations from the core are a lure for potential licensees, whose higher willingness to pay makes attractive the licensing of such innovations by the patentholder ${ }^{27}$.

In Table 5 we display results for a sample restricted to the 22 biggest US firms -with more than $\$ 10$ millions in assets and 500 shareholders, as identified in the Compustat database-. For these firms we have available an important control variable: diversification. Indeed, this variable has the strongest effect on the likelihood (12\%). This result suggests that diversified firms may have a more proactive licensing policy due to a higher awareness of the benefits of pure-revenue licensing- or/and a higher rate of underused patents. The inclusion of this control, however, does not lead to any significant change in the rest of variables. The restriction to the sample of big firms, 
however, does introduce some changes. Scope related variables are no longer significant, suggesting that big firms do not need the protection that this dimension may confer in riskier settings. Originality becomes significant, which reinforces the positive effect of the innovativeness dimension and suggests that it has a greater impact on the decisions of big well-established firms. The control selfcitations received also turns to significant. We observe stronger effects of the variables on the likelihood: the impact of creceive in the core, for instance, is more than two times bigger than it is in the whole sample.

\section{CONCLUSION}

In this paper, we examine the willingness to license patented innovations with the only purpose of extracting revenues, absent any strategic consideration. Our aim is to characterize the technological determinants that affect this willingness at the innovation level. The features of the innovations are meant to capture: its technological attractiveness for potential licensees, the relevance of transaction costs associated to its transfer and the potential to be totally or partially unexploited by the patentholder. These ingredients, we argue, are likely to affect the balance between the revenues from licensing royalties and the drop in revenues due to the introduction of competition and, therefore, the willingness to license by the firm. We consider importance, innovativeness, fit and scope the relevant technological dimensions. 
Using patent data and an original dataset on patented technologies assumed to be devoted to pure-revenue licensing, we find that the mentioned dimensions affect the patentholder's decision. In particular, we find a positive impact of importance in the core, innovativeness and scope and a negative effect of importance out of the core and fit. Moreover, an innovation in a larger portfolio is less likely to be selected for purerevenue licensing whereas if it belongs to a diversified firm, this likelihood increases. Selfcitations and the number of inventors, not considered up to now by the literature, also prove to be informative. Results, therefore, suggest that innovation characteristics are actually relevant on the willingness to license in a setting where strategic concerns are left aside. Nevertheless, this does not mean that firm variables do not play also an important role in licensing decisions. Our findings suggest that the technological features of the innovation should be taken into account as licensing drivers. Last but not least, we should recall that these findings arise in the framework of the chemical industry and they should be interpreted accordingly. Given the particular characteristics of the market for technology in this sector - basically, the long and widespread use of licensing by firms that compete simultaneously in the market for technology and the market for products-, we can not generalize results to the licensing activity of other sectors.

We believe our findings are relevant in a more general perspective, as well. They suggest that transaction costs involved in technology transfer do not affect equally all potential transactions or licensors. Licensing has traditionally emphasized the importance to minimize opportunism, which comes at the price of a very restrictive network that also reduces the possibilities to find a licensee. We show that potential licensors might prefer a contact-network that minimizes the costs to reach partners in 
order to license, among their technologies, those less vulnerable to opportunism, for instance. We must take it into account if we want to derive implications for the claimed necessary development of efficient markets for technology. Note, however, that we examine here the patentholders' incentives to license, not their actual licensing activity. Therefore, in order to extract conclusions on the efficiency of a more open but also riskier licensing market such as the analyzed here, we need to evaluate as well the incentives by the demand side. This research line, however, is left for future research. 


\section{References}

Anand, B.N. and T. Khanna, 2000. "The Structure of Licensing Contracts", Journal of Industrial Economics, 48: 103-135

Arora, A., 1995. "Licensing Tacit Knowledge: Intellectual Property Rights and the Market for Knowhow", Economics of Innovation and New Technology, 4: 41-59.

Arora, A. and A. Fosfuri, 2003. "Licensing the market for technology". Journal of Economic Behaviour and Organization, 52(2), 277-295.

Arora, A., A. Fosfuri and A. Gambardella, 2001. "Markets for Technology: Economics of Innovation and Corporate Strategy", MIT Press, Cambridge, MA.

Arrow, K.J., 1962. "Economic welfare and the allocation of resources for invention”. In:

Nelson, R.R. (Ed.), The Rate and Direction of Inventive Activity: Economic and Social Factors. Princeton Univ. Press, 609-625.

Cassiman, B. and M. Ueda, 2006 “Optimal Project Rejection and New Firm Start-ups,” Management Science, 52 (2), $262-275$.

Cohen, W., R. Nelson and J. Walsh, 2000. "Protecting their intellectual assets: Appropriability conditions and why US manufacturing firms patent or not" NBER WP, 7552

Davis, G.F., K.A. Diekmann and C.H. Tinsley, 1994. "The Decline and Fall of the conglomerate firm in the 1980s" American Sociological Review, 59, 54-570.

Elton, J., B. Shah and J. Voyzey, 2002. "Intellectual Property: Partnering for Profit" The McKinsey Quarterly $\mathrm{N}^{\mathrm{o}} 4$ (Technology)

Fosfuri, A., 2007. "The Licensing Dilemma: Understanding the Determinants of the Rate of Licensing", Strategic Management Journal, forthcoming.

Gallini, N.T., 1984. "Deterrence through market sharing: a strategic incentive for licensing”. American Economic Review 74, 931-941.

Garicano, L. and S. Kaplan, 2001. "The Effects of Business-to-Business E-Commerce on Transaction Costs", Journal of Industrial Economics, 49 (4), 463-485.

Giuri, P., M. Mariani, S. Brusoni, G. Crespi, Francoz, A. Gambardella, W. Garcia-Fontes, A. Geuna, R. González, D. Harhoff, K. Hoisl, Lebas, A. Luzzi, Magazzini, L. Nesta, Nomaler, N. Palomeras, K. Patel, Romanelli, B. and Verspagen, 2005, "Everything you always wanted to know about inventors (but never asked): "Evidence from the PatVal-EU survey", CEPR Discussion Paper 5752.

Hall, B.H., A. Jaffe, and M. Trajtenberg, 2001. "The NBER Patent Citations Data File: Lessons, Insights and Methodological Tools", NBER WP 8498.

Hall, B.H., A. Jaffe and M. Trajtenberg, 2005. "Market Value and Patent Citations", Rand Journal of Economics, Vol.36 (1),16-38.

Henderson, R., 1993. "Underinvestment and Incompetence as Responses to Radical Innovation: Evidence from the Photolithographic Alignment Equipment Industry", Rand Journal of Economics, Vol.24 (2): 248-70, Summer

$\mathrm{Hu}$, A.G., 2003. "Multinational Corporations, Patenting, and Knowledge Flow: The Case of Singapore", Unpublished Manuscript, National University of Singapore. 
Lamoreaux, N., Sokoloff, 1998. "Inventors, Firms and the Market for Technology: US Manufacturing in the Late Nineteenth and Early Twentieth Centuries", Learning by Firms, Organizations and Nations

Lanjouw, J. and M. Schakerman, 1999. "The Quality of Ideas: Measuring Innovation with Multiple Indicators" NBER, WP 7345

Lerner, J., 1994. "The Importance of Patent Scope: An Empirical Analysis" RAND Journal of Economics, 25(2): 319-333

Maddala, G., 1993. “The Econometrics of Panel Data, Vol.II” Edward Edgar Publishing Ltd.

Merges R., 1996. "Contracting into Liability rules: Intellectual Property Rights and Collective Rights Organizations", California Law Review, 84, 5, 1293-1394.

Merges, R.P. and R.R. Nelson, 1990. "On the Complex Economics of Patent Scope" Columbia Law Review, 90: 839-916

Reinganum, J., 1983. "Uncertain Innovation and the Persistence of Monopoly", American Economic Review, 73, 741-748

Rivette, K.G. and D. Kline, 2000. "Discovering New Value in Intellectual Property" Harvard Business Review, January-February: $54-66$

Rockett, K., 1990. "Choosing the competition and patent licensing". Rand Journal of Economics, 21, 1, 161-171.

Shane, S., 2001. "Technological Opportunities and New Firm Creation” Management Science, Vol.47, No.2., 205-220

Sine, W.D., S. Shane and D. Di Gregorio, 2003. "The Halo Effect and Technology Licensing: The influence of Institutional Prestige on the Licensing of University Inventions", Management Science, 49 (4): 478-496.

Song, J., P. Almeida and G. Wu, 2003. "Learning-by-Hiring: When Is Mobility More Likely to Facilitate Interfirm Knowledge Transfer?”, Management Science, Vol. 49, No.4, 351-365

Teece, D., 1986. "Profiting from Technological Innovation: Implications for integration, collaboration, licensing and public policy", Research Policy, 15, p.285-305.

Trajtenberg, M., 1990. “A Penny for your Quotes: Patent citations and the value of innovations" RAND Journal of Economics, 21: 172-187

Trajtenberg, M., R. Henderson and A. Jaffe, 1992. "Ivory Tower versus Corporate Lab: An Empirical Study of Basic Research and Appropriability", NBER, WP 4146

Trajtenberg, M., R. Henderson and A. Jaffe, 1997. "University versus corporate patents. A window on the basicness of invention" Economics of Innovation and New Technology, 5, 19-50.

Williamson, O., 1991. "Comparative Economic Organization. The Analysis of Discrete Structural Alternatives” Administrative Science Quarterly, 36, 4, 269-296.

Winter, S., 1987. "Knowledge and Competence as Strategic Assets" in D. Teece (ed.) The Competitive Challenge - Strategies for Industrial Innovation and Renewal, Ballinger, Cambridge, pp. 159-184. 


\section{Appendix 1}

Table 1. Summary of variables

\begin{tabular}{|c|c|c|}
\hline Variable name & Description & Proxy \\
\hline Citations received & $\begin{array}{l}\text { Number of citations the patent receives } \\
\text { from subsequent patents }\end{array}$ & Importance \\
\hline Citations made & $\begin{array}{l}\text { Number of citations the patent makes to } \\
\text { previous patents }\end{array}$ & Innovativeness \\
\hline Originality & $\begin{array}{l}\text { Herfindhal index on the spread of } \\
\text { citations made to different patent classes }\end{array}$ & Innovativeness \\
\hline Claims & $\begin{array}{l}\text { Number of sentences describing the } \\
\text { invention }\end{array}$ & Scope \\
\hline Generality & $\begin{array}{l}\text { Herfindhal index on the spread of } \\
\text { citations received from different patent } \\
\text { classes }\end{array}$ & Scope \\
\hline Core & $\begin{array}{l}\text { Dummy equal to one if the class of the } \\
\text { patent is among the highest frequent } \\
(>10 \%) \text { patent classes in the firm's } \\
\text { portfolio (period 1995-99) }\end{array}$ & Strategic fit \\
\hline Inventors & $\begin{array}{l}\text { Number of inventors responsible for the } \\
\text { innovation listed in the patent }\end{array}$ & $\begin{array}{l}\text { Technological } \\
\text { control }\end{array}$ \\
\hline Self-citations received & $\begin{array}{l}\text { Share of citations received from patents } \\
\text { by the same firm }\end{array}$ & $\begin{array}{l}\text { Technological } \\
\text { control }\end{array}$ \\
\hline Self-citations made & $\begin{array}{l}\text { Share of citations made to patents by the } \\
\text { same firm }\end{array}$ & $\begin{array}{l}\text { Technological } \\
\text { control }\end{array}$ \\
\hline Category dummy & $\begin{array}{l}\text { Technological category that corresponds } \\
\text { to the patent primary class }\end{array}$ & $\begin{array}{l}\text { Technological } \\
\text { control }\end{array}$ \\
\hline Application year dummy & $\begin{array}{l}\text { Year in which the firm submits the patent } \\
\text { to the Patent Office }\end{array}$ & Time control \\
\hline Portfolio & $\begin{array}{l}\text { Number of patents granted to the firm (in } \\
\text { any technological category, 1980-1996) }\end{array}$ & Firm control \\
\hline
\end{tabular}

\begin{tabular}{|l|l|l|}
\hline Diversification & Diversification measure & Firm control \\
\hline
\end{tabular}


Table 2. Descriptive Statistics

\begin{tabular}{|c|c|c|c|c|c|c|c|}
\hline VARIABLES & $\begin{array}{r}\text { Mean } \\
(\mathrm{N}=9241)\end{array}$ & Median & Min & $\operatorname{Max}$ & $\begin{array}{r}\text { Mean } \\
Y=0\end{array}$ & $\begin{array}{r}\text { Mean } \\
Y=1\end{array}$ & $\begin{array}{c}\text { Difference } \\
\text { of meansל }\end{array}$ \\
\hline Citations received & 4.117 & 2 & 0 & 143 & 4.125 & 4.037 & $\begin{array}{c}.0880 \\
(.2563)\end{array}$ \\
\hline Citations made & 8.051 & 5 & 0 & 161 & 7.926 & 9.199 & $\begin{array}{c}-1.272 * * * \\
(.3540)\end{array}$ \\
\hline Originality & .3784 & .4444 & 0 & .9246 & .3744 & .4151 & $\begin{array}{c}-.0407 * * * \\
(.0102)\end{array}$ \\
\hline Claims & 12.84 & 10 & 1 & 183 & 12.61 & 15.08 & $\begin{array}{c}-2.472 * * * \\
(.3933)\end{array}$ \\
\hline Generality & .2238 & 0 & 0 & .9204 & .2244 & .2179 & $\begin{array}{c}.0065 \\
(.0100) \\
\end{array}$ \\
\hline Core & .3059 & 0 & 0 & 1 & .3031 & .3318 & $\begin{array}{c}.0287 * * \\
(.0731)\end{array}$ \\
\hline Inventors & 2.949 & 3 & 1 & 16 & 2.941 & 3.024 & $\begin{array}{l}.0825^{*} \\
(.0625)\end{array}$ \\
\hline Self-citations received & .1749 & 0 & 0 & 1 & .1777 & .1488 & $\begin{array}{c}.0288 * * * \\
(.0109)\end{array}$ \\
\hline Self-citations made & .2253 & .0667 & 0 & 1 & .2299 & .1830 & $\begin{array}{c}.0469 * * * \\
(.0106) \\
\end{array}$ \\
\hline Application year & 1990 & 1990 & 1982 & 1999 & 1989.9 & 1991.9 & $\begin{array}{c}-1.913 * * * \\
(.1561)\end{array}$ \\
\hline
\end{tabular}

'Mean comparison t-test on equality of means $\left(\mathrm{H}_{0}:\right.$ mean $(0)$-mean $\left.(1)=0\right)$

Significance level: .01***; .05**

Table 3. Correlations

\begin{tabular}{|c|c|c|c|c|c|c|c|c|c|c|}
\hline & (1) & (2) & (3) & (4) & (5) & (6) & (7) & (8) & (9) & (10) \\
\hline (1) creceive & -- & & & & & & & & & \\
\hline (2) cmade & .0670 & -- & & & & & & & & \\
\hline (3) original & .0613 & .3645 & -- & & & & & & & \\
\hline (4) claims & .1317 & .2059 & .0978 & -- & & & & & & \\
\hline (5) general & .5198 & .0206 & .1701 & .0877 & -- & & & & & \\
\hline (6) core & $.0107 *$ & .0335 & -.1037 & $-.0077 *$ & -.0781 & -- & & & & \\
\hline (7) inventors & -.0645 & -.0385 & -.0642 & -.0331 & -.0771 & .0998 & -- & & & \\
\hline (8) selfcd & .1474 & .0495 & -.0216 & .0470 & .1539 & .0979 & -.0020 & -- & & \\
\hline (9) selfct & $-.0175^{*}$ & $-.0074 *$ & -.0419 & $.0112 *$ & -.0426 & .1046 & $-.0137 *$ & .1023 & -- & \\
\hline (10) portfolio & $.0137 *$ & $-.0130 *$ & $-.0152 *$ & -.0227 & $-.0150 *$ & -.1060 & -.0225 & .0614 & .1079 & -- \\
\hline (11) appyear & -.3235 & .1566 & .0530 & .0278 & -.3945 & .1178 & .1680 & -.0902 & .0232 & $.0168 *$ \\
\hline
\end{tabular}

* Significance level bigger than .05 
Table 4: Probit Random Effects, Marginal Effects at the Median

\begin{tabular}{|c|c|c|c|c|}
\hline Variables & \begin{tabular}{|l|} 
Specification 1 \\
\end{tabular} & Specification 2 & Specification 3 & Specification 4 \\
\hline \multicolumn{5}{|l|}{ Importance } \\
\hline Citations received & $\begin{array}{l}.0030 \\
(.0039)\end{array}$ & $\begin{array}{l}-.0035 \\
(.0047)\end{array}$ & $\begin{array}{l}-.0039 \\
(.0049)\end{array}$ & $\begin{array}{l}.0139 * * * \\
(.0049)\end{array}$ \\
\hline \multicolumn{5}{|l|}{ Innovativeness } \\
\hline Citations made & $\begin{array}{l}.0072 * \\
(.0046) \\
\end{array}$ & $\begin{array}{l}.0088^{*} \\
(.0053) \\
\end{array}$ & $\begin{array}{l}.0085^{*} \\
(.0054) \\
\end{array}$ & $\begin{array}{r}-.0079 * * \\
(.0041) \\
\end{array}$ \\
\hline Originality & & $\begin{array}{l}.0095 \\
(.0169) \\
\end{array}$ & $\begin{array}{l}.0084 \\
(.017) \\
\end{array}$ & $\begin{array}{l}.0086 \\
(.0132) \\
\end{array}$ \\
\hline \multicolumn{5}{|l|}{ Scope } \\
\hline Claims & $\begin{array}{l}.0081^{* * *} \\
(.0043)\end{array}$ & $\begin{array}{l}.0081 * * \\
(.0041)\end{array}$ & $\begin{array}{l}.0071^{*} \\
(.004)\end{array}$ & $\begin{array}{l}.0046^{*} \\
(.0030)\end{array}$ \\
\hline Generality & & $\begin{array}{l}.0370 * \\
(.0202) \\
\end{array}$ & $\begin{array}{l}.0361 * \\
(.0203) \\
\end{array}$ & $\begin{array}{l}.0379 * * * \\
(.0168) \\
\end{array}$ \\
\hline \multicolumn{5}{|l|}{ Strategic fit } \\
\hline Core & $\begin{array}{l}-.0125^{*} \\
(.0073)\end{array}$ & $\begin{array}{l}-.0104^{*} \\
(.0068)\end{array}$ & $\begin{array}{l}.0081 \\
(.0067)\end{array}$ & $\begin{array}{l}.0252 * * * \\
(.0087)\end{array}$ \\
\hline \multicolumn{5}{|l|}{ Interactions } \\
\hline Core $x$ Creceived & & & & $\begin{array}{l}.0260 * * * \\
(.0084) \\
\end{array}$ \\
\hline \multicolumn{5}{|l|}{ Technological controls } \\
\hline Inventors & & & $\begin{array}{l}.0153 * * * \\
(.007)\end{array}$ & $\begin{array}{l}.0152 * * * \\
(.0057) \\
\end{array}$ \\
\hline Selfcitations received & & & $\begin{array}{l}-.0057 \\
(.014) \\
\end{array}$ & $\begin{array}{l}-.0093 \\
(.0112) \\
\end{array}$ \\
\hline Selfcitations made & & & $\begin{array}{l}-.0447 * * * \\
(.0185)\end{array}$ & $\begin{array}{l}-.0368 * * * \\
(.0153)\end{array}$ \\
\hline Technological category & $\begin{array}{l}-.0280 * * * \\
(.0098)\end{array}$ & $\begin{array}{l}-.0255^{* * *} * \\
(.0093)\end{array}$ & $\begin{array}{l}-.0317 * * * \\
(.0078)\end{array}$ & $\begin{array}{l}-.0216^{* * * *} \\
(.0078)\end{array}$ \\
\hline Application year & Included & Included & Included & Included \\
\hline \multicolumn{5}{|l|}{ Firm controls } \\
\hline Portfolio & $\begin{array}{l}-.0330 * * * \\
(.0078)\end{array}$ & $\begin{array}{l}.0307 * * * \\
(.0076) \\
\end{array}$ & $\begin{array}{l}.0317 * * * \\
(.0079) \\
\end{array}$ & $\begin{array}{l}.0314 * * * \\
(.0085)\end{array}$ \\
\hline Rho & .2 & .2 & $.2368 * * *$ & $.3435^{* *}$ \\
\hline $\mathrm{N}$ & 8583 & 8553 & 8553 & 8553 \\
\hline Groups & 87 & 87 & 87 & 87 \\
\hline Wald $\chi^{2}-$ test & 205.66 *** & $208.14 * * *$ & $254.62 * * *$ & $368.69 * * *$ \\
\hline
\end{tabular}

For dummy variables, effect of a discrete change from 0 to 1

Standard errors of marginal effects in parentheses.

Confidence level of the coefficient (not marginal effect) at 1\%***, 5\%**, $10 \% *$. 
Table 5: Probit Random Effects, Marginal Effects at the Median. Large firms.

\begin{tabular}{|c|c|c|c|c|}
\hline Variables & Specification 1 & Specification 2 & Specification 3 & Specification 4 \\
\hline \multicolumn{5}{|l|}{ Importance } \\
\hline Citations received & \begin{tabular}{|l}
-.0033 \\
$(.0054)$
\end{tabular} & \begin{tabular}{|l}
-.0106 \\
$(.0602)$
\end{tabular} & $\begin{array}{l}.0099 \\
(.0092)\end{array}$ & $\begin{array}{l}-.0340 * * * \\
(.0149)\end{array}$ \\
\hline \multicolumn{5}{|l|}{ Innovativeness } \\
\hline Citations made & $\begin{array}{l}-.0087 \\
(.0064)\end{array}$ & $\begin{array}{l}-.0195 * * \\
(.0576)\end{array}$ & $\begin{array}{l}-.0220 * * \\
(.0111)\end{array}$ & $\begin{array}{l}-.0257 * * * \\
(.0126)\end{array}$ \\
\hline Originality & & $\begin{array}{l}.0680 * * \\
(.2148)\end{array}$ & $\begin{array}{l}.0657 * * \\
(.0375)\end{array}$ & $\begin{array}{l}.0718^{*} \\
(.0426)\end{array}$ \\
\hline \multicolumn{5}{|l|}{ Scope } \\
\hline Claims & $\begin{array}{l}.0002 \\
(.0065)\end{array}$ & \begin{tabular}{|l|}
.0103 \\
$(.0479)$
\end{tabular} & \begin{tabular}{|l|}
.0082 \\
$(.0078)$
\end{tabular} & \begin{tabular}{|l|}
.0092 \\
$(.0089)$
\end{tabular} \\
\hline Generality & & $\begin{array}{l}.0311 \\
(.2156) \\
\end{array}$ & \begin{tabular}{|l|l|}
.0253 \\
$(.0348)$ \\
\end{tabular} & \begin{tabular}{|l|}
.0493 \\
$(.0429)$ \\
\end{tabular} \\
\hline \multicolumn{5}{|l|}{ Strategic fit } \\
\hline Core & $\begin{array}{l}-.0207 \\
(.0152)\end{array}$ & $\begin{array}{l}-.0058 \\
(.0930)\end{array}$ & $\begin{array}{l}-.0055 \\
(.0152)\end{array}$ & $\begin{array}{l}-.0688 * * * \\
(.0279)\end{array}$ \\
\hline \multicolumn{5}{|l|}{ Interactions } \\
\hline Core $x$ Creceived & & & & $\begin{array}{l}.0617 * * * \\
(.0251) \\
\end{array}$ \\
\hline \multicolumn{5}{|l|}{$\begin{array}{l}\text { Technological } \\
\text { controls }\end{array}$} \\
\hline Inventors & & & $\begin{array}{l}.0334 * * * \\
(.0134)\end{array}$ & $\begin{array}{l}.0405 * * * \\
(.0155)\end{array}$ \\
\hline $\begin{array}{l}\text { Self citations } \\
\text { received }\end{array}$ & & & $\begin{array}{l}-.0482 * * \\
(.0284)\end{array}$ & $\begin{array}{l}-.0629 * * \\
(.0338)\end{array}$ \\
\hline Self citations made & & & $\begin{array}{l}.0595 * * \\
(.0321) \\
\end{array}$ & $\begin{array}{l}.0742 * * * \\
(.0377) \\
\end{array}$ \\
\hline $\begin{array}{l}\text { Technological } \\
\text { category }\end{array}$ & $\begin{array}{l}-0.245^{*} \\
(.0138)\end{array}$ & $\begin{array}{l}-.0355 * * \\
(.1357)\end{array}$ & $\begin{array}{l}. .0406 * * \\
(.0179)\end{array}$ & $\begin{array}{l}-.0502 * * \\
(.0210)\end{array}$ \\
\hline Application year & Included & Included & Included & Included \\
\hline \multicolumn{5}{|l|}{ Firm controls } \\
\hline Portfolio & $\begin{array}{l}-.0404 * * * \\
(.0106) \\
\end{array}$ & $\begin{array}{l}-.0594 * * * \\
(.0735) \\
\end{array}$ & $\begin{array}{l}-.0534 * * * \\
(.0174) \\
\end{array}$ & $\begin{array}{l}-.0502 * * * \\
(.0210) \\
\end{array}$ \\
\hline Diversification & $\begin{array}{l}.1250 * * * \\
(.0211) \\
\end{array}$ & $\begin{array}{l}.1080 * * * \\
(.1225) \\
\end{array}$ & \begin{tabular}{|l}
$.1137 * * *$ \\
$(.0330)$ \\
\end{tabular} & \begin{tabular}{|l}
$.1196 * * *$ \\
$(.0337)$ \\
\end{tabular} \\
\hline Rho & $.2009 * *$ & $.3891 * * *$ & $.3666 * *$ & $.3833 * *$ \\
\hline $\mathrm{N}$ & 4209 & 3151 & 3151 & 3151 \\
\hline Groups & 22 & 22 & 22 & 22 \\
\hline Wald $\chi^{2}-$ test & $144.84 * * *$ & $103.72 * * *$ & $116.25 * * *$ & $124.56 * * *$ \\
\hline
\end{tabular}

For dummy variables, effect of a discrete change from 0 to 1

Standard errors of marginal effects in parentheses.

Confidence level of the coefficient (not marginal effect) at 1\%***, 5\%**, 10\%*. 
Figure 1. Conditional effect plot for Importance.

Rest of variables at the mean, except for core

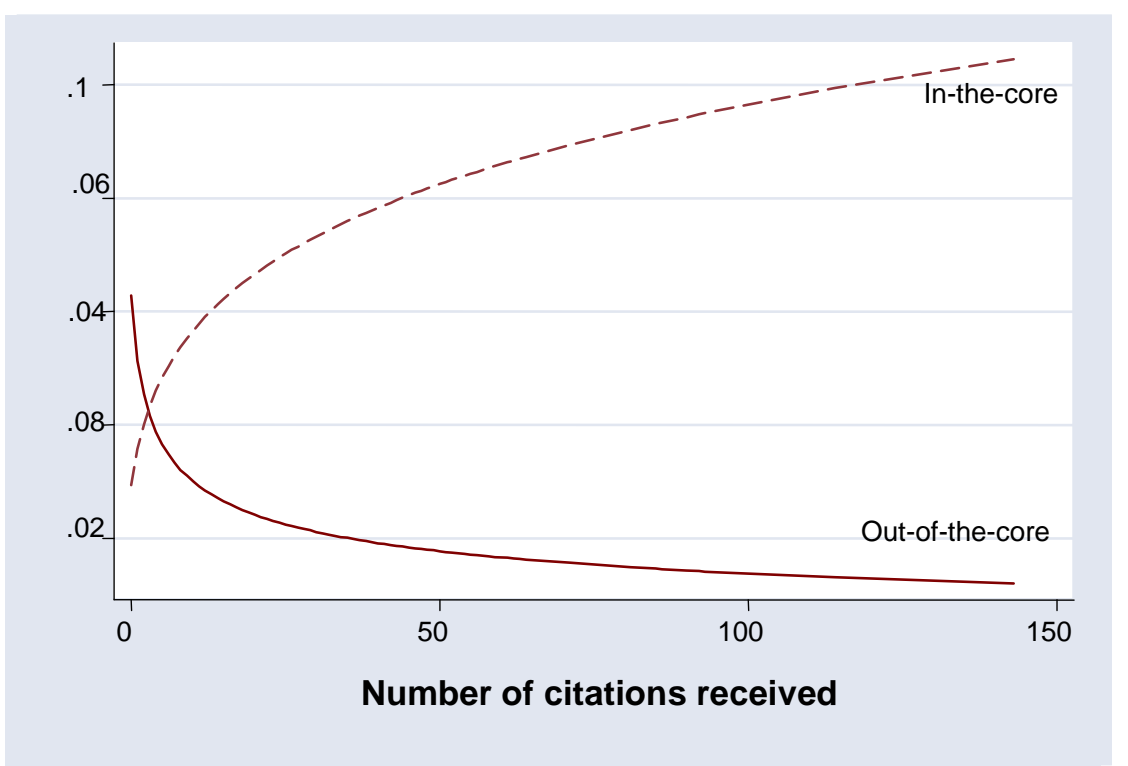




\section{Appendix 2}

Table 6. List of patentholders sampled from yet2.com

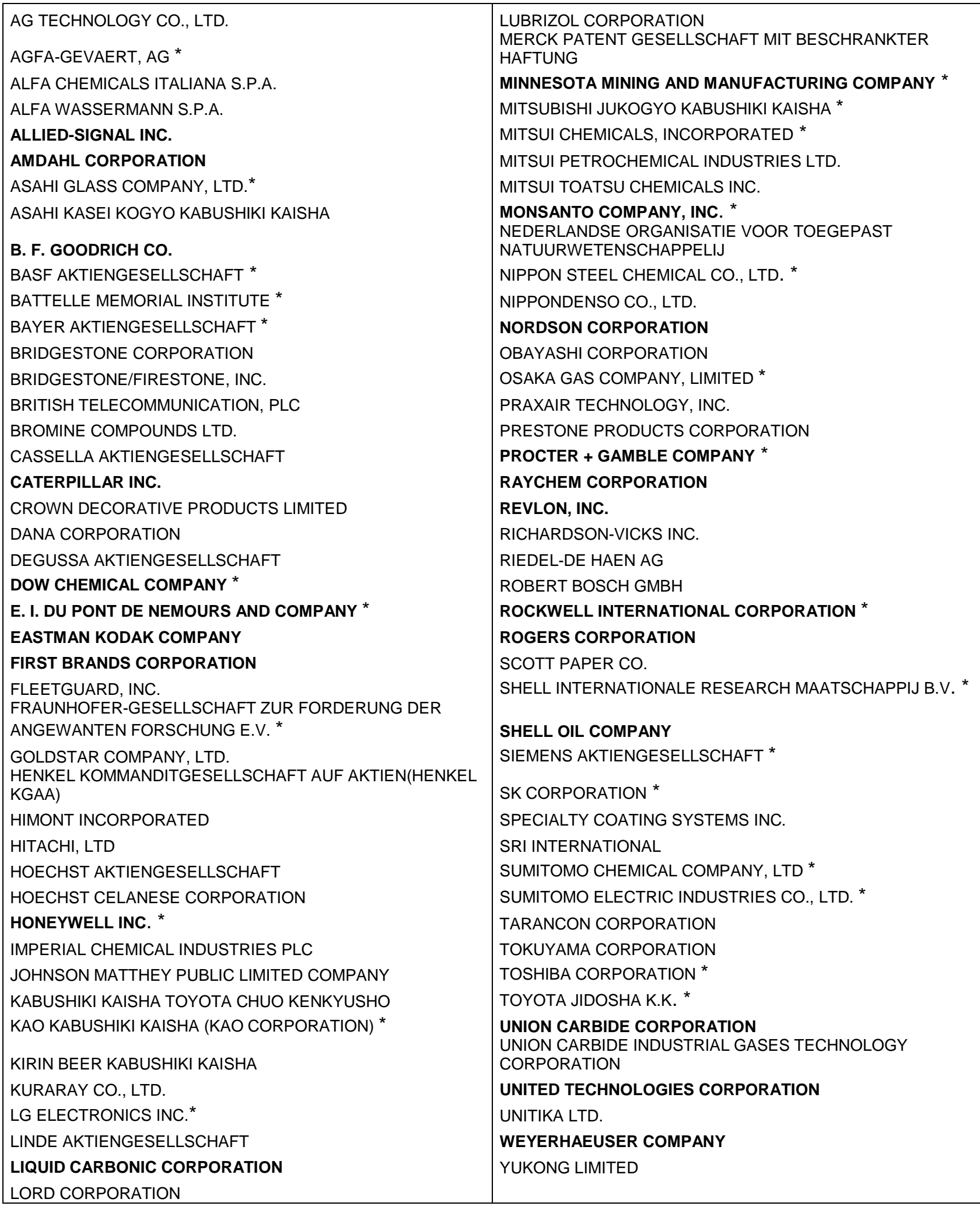

In bold, firms identified in the Compustat database that form the subsample of large firms

Followed by ${ }^{*}$, founding sponsors of yet2.com (at the time of data collection, 2000) 
Figure 2. Some details on yet2.com

Date of creation: February 2000

\section{Co-Founders:}

Ben du Pont, 36, former manager at DuPont of Lycra brand and informally responsible for finding new uses for DuPont's technology.

Chris De Bleser, 44, former manager of the technical and digital-imaging business at Polaroid.

Fee structure (at the moment of data collection, 2002):

- For buyers, according to access levels:

Level 1. Registration and access free. It includes basic description of the technology, owner not disclosed.

Level 2. Paid access (around 25\$) to view (1) a 3 page description (*) of the technology and (2) proposed terms and conditions of licensee

Level 3. Introduction free or for a fee, as set by the provider. On successful deals, yet2.com refunds any introduction fee

- For sellers:

To list: \$250 per year per listing. Some memberships include listing fees.

-yet2.com does some basic checking, verifying that the company actually holds the patent it is attempting to license-.

To get introduced: No cost.

On successful deals: $10 \%$ of resulting revenue (minimum of $\$ 5000$ and capped at $\$ 50.000$ ).

(*) Description of the technology is an important feature of this marketplace. According to yet2.com, patents only cover a few of the information potential buyers need. This will include, for instance, suggested applications, the technical and/or commercial assistance by the seller, the development stage, the technology benefit or a clear description of the technology. 


\section{Figure 3. The front page of a TechPak (a technology) listed in yet2.com}
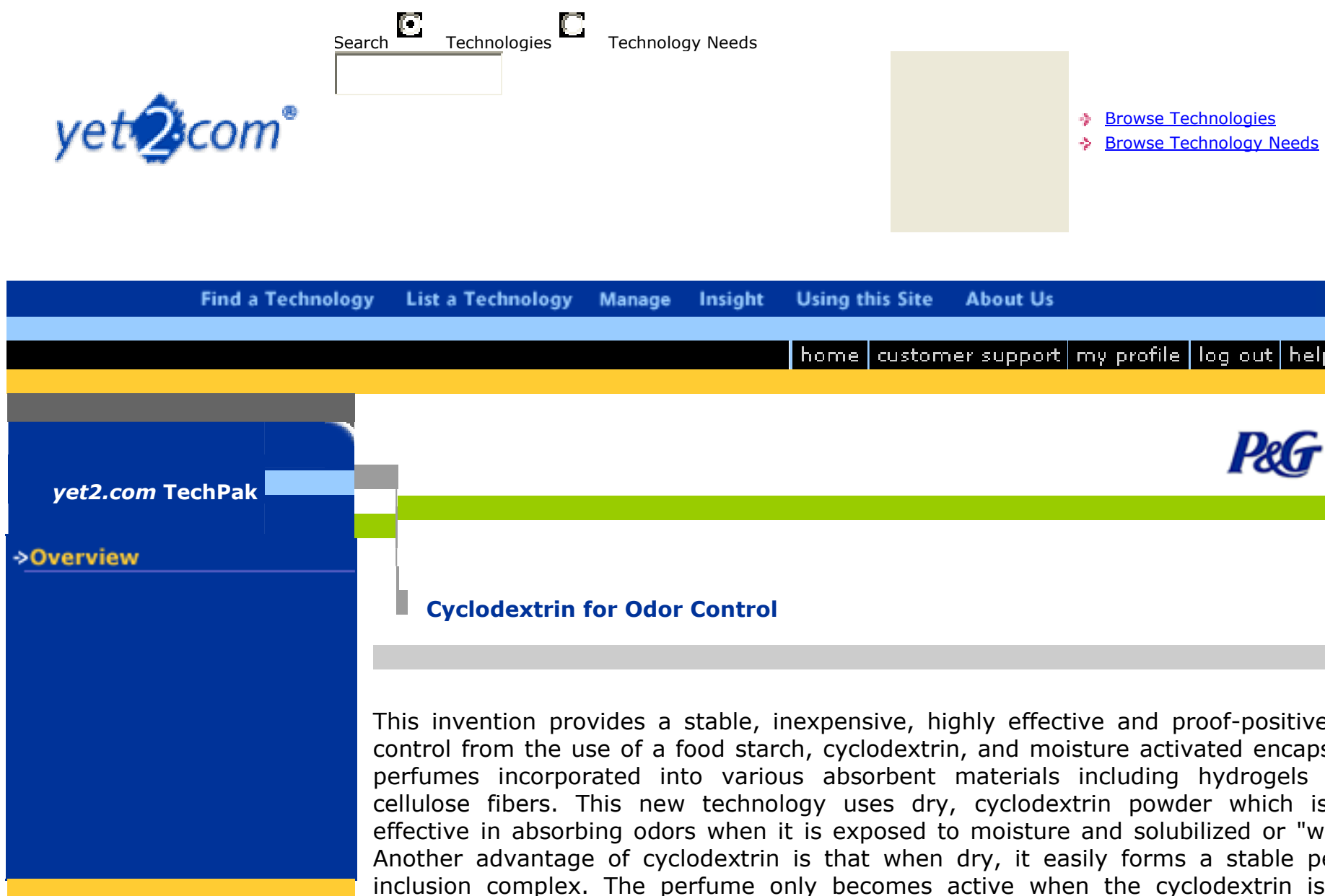

\section{Actions}

Request an Introduction

Ask the Owner a Question

Email This TechPak to a Friend

Print This TechPak

Return to Search Results

\section{Cyclodextrin for Odor Control}

This invention provides a stable, inexpensive, highly effective and proof-positive odorcontrol from the use of a food starch, cyclodextrin, and moisture activated encapsulated perfumes incorporated into various absorbent materials including hydrogels and/or cellulose fibers. This new technology uses dry, cyclodextrin powder which is most effective in absorbing odors when it is exposed to moisture and solubilized or "wetted". Another advantage of cyclodextrin is that when dry, it easily forms a stable perfume inclusion complex. The perfume only becomes active when the cyclodextrin is being solubilized and removing odor; thus acting as a "scent signal" which indicates when the composition is working. Finally, cyclodextrin is easy to manufacture, safe and easy to handle, and easy to use in large scale, high speed manufacturing operations. It can be combined with other odor absorbent materials such as activated carbon or zealots. The cyclodextrin based composition can easily be added to a fluid absorption material such as a hydrogel and/or cellulose fibers. Such an invention could be readily used in typical consumer goods used for controlling bodily odors, including baby diapers, panty liners, and other general sanitary items. It might also be used in paper towels or napkins, portable toilets, toilet freshener, cat litter, and carpet and upholstery cleaners. In concert with a hydrogel and anti-microbial agents, it might have military uses specifically in detection and protection against liquid vapor borne biological agents. Specifics of composition (size of particles, proportions, etc), analyses, stability, and manufacture (typical applications) are included that would result in shortening the time to market.

\section{Benefits Summary}

This new technology uses dry, cyclodextrin powder which is most effective in absorbing odors when it is exposed to moisture and solubilized or "wetted". Another advantage of cyclodextrin is that when dry, it easily forms a stable perfume inclusion complex. more

\section{Development Summary}

This technology is currently being commercialized. more

\section{IP Summary}

This technology is supported by 2 US patents. The most recent year of issue is 1998. more 


\section{Footnotes}

${ }^{1}$ To mention some examples of technologies coming from or being applied to external industries: the fibreglass cables in the telephone industry that were developed by a glass company, Coming; a technology developed by Boeing as part of a military application that was used for Touchbridge Systems as part of an integrated networking system in the home environment; a new technology for expanding the capacity of fiber-optic networks discovered by Polaroid that became quite valuable to telecommunication companies.

${ }^{2}$ Procter \& Gamble, for instance, uses both. It hired a panel of technologists to identify new uses for a molecule initially used as a low-fat ingredient for snack foods. The more valuable alternative application identified was a pollutant remover (Elton et al., 2002). The firm also uses an online marketplace, yet2.com, to try to license its technologies either to competitors in the cosmetic industry or to firms from distant sectors and regions such as a Korean firm in the water purification industry (www.yet2.com).

${ }^{3}$ Our choice is driven by the features of the innovation that can be captured by the characteristics of the patent that protects it, due to our reliance on patent data.

${ }^{4}$ These characteristics guarantee that they have different options available -not necessarily substitutes- in order to exploit their technologies, which range from in-house development to different licensing strategies.

${ }^{5}$ We must be aware that patented innovations present a strongly skewed value distribution, which means that most of them have no commercial value (Trajtenberg et al., 1997).

${ }^{6}$ Think on the laser, that has a huge variety of uses.

${ }^{7}$ Legal broadness is achieved by the most generic possible description of the technology, in such a way that the patent builds a wall of protection around the particular technology of interest.

${ }^{8} \mathrm{~A}$ patent not offered for pure revenue licensing can be devoted to different uses: own development, and/or licensing, blocking competitors or simply not used at all. Similarly, a patent devoted to purerevenue licensing can be simultaneously internally developed, non-internally developed, licensed or even used to block competitors - even though the distribution among these uses is likely to differ in the two groups-. However, it is not the current use per se that excludes or favors pure-revenue licensing but the technological dimension that also affects the current use. Therefore, note that we are not comparing pure revenue licensing with the rest of possible patent uses. 
${ }^{9}$ The other important web-based firm operating in this area was Delphion.com, a spin-off of IBM. It was not positioned as a B2B exchange but as a service for research and analysis of patents and related intellectual property information, including the availability for license -if patent holders paid to include it. From the end of 2002, Delphion, nowadays part of Thomson Corporation, and yet2.com partnered to create an integrated listing of licensable technologies and patent information. In the university segment survives techex.com, born from Yale University in order to commercialize university patents and acquired by UTEK Corp. in 2002.

${ }^{10}$ See details on fees and other details on the operating of yet2.com in 2002 in Figures $2 \& 3$ and Table 6.

${ }^{11}$ Note that we are only able to identify the supply side of this market, which reflects precisely the willingness to license by patentholders. yet2.com does not provide details on the actual transactions.

${ }^{12}$ We exclude governmental agencies or research institutes, since their motivations to license differ from those by firms with development capabilities.

${ }^{13}$ The USPTO assigns the patents to a primary and some secondary patent classes. We use the primary class in order to assign the patent to an industrial sector according to the correspondence between classes and industrial sectors established by Hall et al (2001).

${ }^{14}$ Even though patents not present in yet2.com could be listed in any other Internet marketplace, we do not consider it likely. First, the customized fee structure favours the number of listings, since it allows shifting from a variable fee per listing to a fixed fee. Second, a group of firms listing in yet2.com are "founding sponsors", big R\&D intensive corporations that agreed to help building the marketplace by posting their technologies online exclusively there (see list in Table 8). Third, a portal created from the chemical industry is likely to attract the activity in this area.

${ }^{15}$ The population that constitutes the comparison group sums up to 61000 patents. Random sampling is used in empirical works (Hu, 2003) involving comparison between different patent groups. Alternatively, matching samples are also used (Trajtenberg et al, 1992). We choose the first method in order to compare the two groups of patents along all dimensions.

${ }^{16}$ This assumption implies that we take for granted that one innovation is protected by one patent. This is not necessarily the case: the number of patents that cover an innovation depends mainly on the sector. As Cohen et al (2000) point out, in chemicals a technology is protected by a few number of patents while in electronics the number can reach hundreds. Even though data is available at yet2.com at the innovation 
level, we are not able to use this information in our empirical analysis, since we can only build a control group at the patent but not at the innovation level.

${ }^{17}$ Originalit $y_{j}=1-\sum_{k}^{n_{j}} s_{j k}^{2}$, where $s_{j k}^{2}=$ percentage of citations made by patent $j$ that belong to patent class $k$ out of $\mathrm{n}_{\mathrm{j}}$ patent classes

${ }^{18}$ We consider the highest frequent patent classes those that account for more than a $5 \%$ of the firm's portfolio at the five-year time span before the decision of commercialization in the Internet (1995-1999). Main results do not change if we use instead a $10 \%$ patent share.

${ }^{19}$ Its expression is parallel to that of originality, with citations made being replaced by citations received.

${ }^{20}$ This measure can be highly endogenous, since the firm decides how to break down the actual blocks of the invention. However, firm discretion is constrained by the type of technology and Patent Office examiners.

${ }^{21}$ These measures are only available for a certain set of firms: public US-based firms with more than $\$ 10$ millions in assets and 500 shareholders.

${ }^{22}$ It takes the form $\sum p_{i} \ln \left(1 / p_{i}\right)$, where $p_{i}$ is the proportion of the firm's sales made in segment $i$. We retrieve this information from the Form 10-K filed with the Securities and Exchange Commission (SEC). ${ }^{23}$ In order not to lose observations with a zero value when taking logarithms, we add up one to the original variable before doing the transformation.

${ }^{24}$ We compute the marginal effect at the median of the log transformed variable in order to easily identify the original value it corresponds to (i.e. the median of the original variable).

${ }^{25}$ The more fragmented the sources of know-how, the more difficult is the knowledge transfer expected but, at the same time, the easier for the patent holder to keep the relevant information under control.

${ }^{26}$ This is the median value of this variable. Note that this calculation does not result straightforward from the data reported in the table, that are marginal effects and where the variables are in logarithms.

${ }^{27}$ Note, as an illustration, the case of one of the highest cited patents in our sample - with patent protection granted in nine extra countries, fact that emphasizes its importance-. It belongs to Procter \& Gamble's core technologies and is related to odour control. According to information provided in the yet2.com site, this is a commercialized technology that its patentholder is trying to license, suggesting potential applications in the hygiene, food or animal health industries. 